\title{
A Single Amino Acid of NlaPro of Papaya ringspot virus Determines Host Specificity for Infection of Papaya
}

\author{
Kuan-Chun Chen, ${ }^{1}$ Chu-Hui Chiang, ${ }^{2}$ Joseph A. J. Raja, ${ }^{1}$ Fang-Lin Liu, ${ }^{1}$ Chun-Hsi Tai, ${ }^{1}$ and \\ Shyi-Dong Yeh ${ }^{1}$ \\ ${ }^{1}$ Department of Plant Pathology, National Chung Hsing University, Taichung, Taiwan, R.O.C.; ${ }^{2}$ Department of Molecular \\ Biotechnology, Da Yeh, University, Chang Hwa, Taiwan, R.O.C.
}

Submitted 25 November 2007. Accepted 2 April 2008.

\begin{abstract}
Most strains of Papaya ringspot virus (PRSV) belong to type $W$, causing severe loss on cucurbits worldwide, or type $P$, devastating papaya in tropical areas. While the host range of PRSV $W$ is limited to plants of the families Chenopodiaceae and Cucuribitaceae, PRSV $P$, in addition, infects plants of the family Caricaceae (papaya family). To investigate one or more viral genetic determinants for papaya infection, recombinant viruses were constructed between PRSV P-YK and PRSV W-CI. Host reactions to recombinant viruses indicated that the viral genomic region covering the C-terminal region (142 residues) of NIaVPg, full NIaPro, and N-terminal region (18 residues) of $\mathrm{NIb}$, is critical for papaya infection. Sequence analysis of this region revealed residue variations at position 176 of NIaVPg and positions 27 and 205 of NIaPro between type $P$ and $W$ viruses. Host reactions to the constructed mutants indicated that the amino acid $\mathrm{Lys}^{27}$ of NIaPro determines the host-specificity of PRSV for papaya infection. Predicted three-dimensional structures of NIaPros of parental viruses suggested that $\mathrm{Lys}^{27}$ does not affect the protease activity of NIaPro. Recovery of the infected plants from certain papaya-infecting mutants implied involvement of other viral factors for enhancing virulence and adaptation of PRSV on papaya.
\end{abstract}

Additional keywords: host-specificity determinant.

Papaya (Carica papaya L.) is widely grown in the tropical and subtropical areas. The destructive papaya ringspot disease caused by Papaya ringspot virus (PRSV) is a major obstacle to large-scale papaya production (Purcifull et al. 1984). PRSV is a member of the genus Potyvirus of the family Potyviridae, the largest and most economically important plant virus genus (Francki et al. 1991). PRSV is transmitted by aphids in a nonpersistent manner in nature (Purcifull et al. 1984). The virions of PRSV are flexuous particles of $780 \times 12 \mathrm{~nm}$. The genome consists of a single-stranded RNA of positive polarity (De La Rosa and Lastra 1983; Purcifull et al. 1984). PRSV has a coat protein (CP) subunit of $36 \mathrm{kDa}$ (Gonsalves and Ishii 1980; Purcifull and Hiebert 1979) and induces cylindrical (CI) (Purcifull and Edwardson 1967) and amorphous cytoplasmic inclusions (AI) (Martelli and Russo 1976). The genomic RNA of PRSV is of 1,0326 nucleotides (nt), with a genetic organization of 5'-P1, HC-Pro, P3, CIP, 6K, NIa (encoding NIaVPg

Corresponding author: Shyi-Dong Yeh; Telephone: +886-4-22877021; Fax: +886-4-22852501; E-mail: sdyeh@nchu.edu.tw and NIaPro [Dougherty and Dawn Parks 1991]), NIb, and CP3' (Dougherty and Carrington 1988; Yeh et al. 1992).

Most strains of PRSV were classified into two groups, type W (PRSV W), infecting only the plants of the families Chenopodiaceae and Cucurbitaceae, and type P (PRSV P), infecting, in addition, the plants of the family Caricaceae (Purcifull et al. 1984; Yeh et al. 1984). Because of its natural infectivity on cucurbits, PRSV W was first described as Watermelon mosaic virus 1 (WMV-1) (Webb and Scott 1965) and was considered for several years as a distinct potyvirus. However, WMV-1 and PRSV isolates are serologically indistinguishable, when tested against antibodies to viral particles (Gonsalves and Ishii 1980), CP (Yeh et al. 1984), CI protein (Yeh and Gonsalves 1984b), or AI protein (De Mejia et al. 1985; Yeh and Gonsalves 1985). Furthermore, mild strains of PRSV are able to cross-protect cucurbits against PRSV and WMV-1 (Yeh and Gonsalves 1984a), while cucurbit genes responsible for resistance to WMV-1 confer resistance to PRSV (Provvidenti and Gonsalves 1982; Yeh et al. 1984). Based on the similarities in serological properties, cross-protection, and host resistance, WMV-1 is therefore reclassified as a specific cucurbit-infecting type of PRSV, designated as PRSV W, while the papaya-infecting type is classified as PRSV P (Purcifull et al. 1984; Yeh et al. 1984). According to symptoms induced on papaya, PRSV P isolates are further categorized into wilting and mosaic strains (Chang 1979). In Taiwan, the mosaic strains of PRSV $P$ are more prevalent (Chang 1979).

Because of narrow and subtle genetic differences, strains of PRSV P and PRSV W of a geographical zone cannot be distinguished by their genomic sequences (Bateson et al. 1994, 2002), though they can be distinguished by host specificityability or inability to infect papaya. Various phylogenetic analyses of the isolates of PRSV (Bateson et al. 1994, 2002; Davis and Ying 1999; Noa-Carrazana et al. 2007) revealed close genetic relationship of the isolates collected within a geographical zone and their divergence, as a group, from those of other geographical zones. These studies support possible indigenous origin of papaya-infecting PRSV $\mathrm{P}$ viruses from local cucurbit-infecting PRSV W viruses by mutation.

The present study was directed to analyze the genetic determinants between PRSV P and PRSV W viruses accounting for papaya infectability and to evaluate the proposed PRSV mutational evolutionary hypothesis. Host assays with recombinant viruses generated between a type $\mathrm{P}$ virus PRSV P-YK (Wang and Yeh 1997) and a type W virus PRSV W-CI (Wang and Yeh 1998) revealed the importance of NIaVPg and NIaPro for papaya infection. Further analyses with site-specific mutant viruses demonstrated that amino acid 27 of NIaPro determines the ability for infecting papaya. 


\section{RESULTS}

The infectivity of in vitro and in vivo infectious clones of P-YK and W-CI.

The parental P-type PRSV strain P-YK (Wang and Yeh, 1997) and the W-type strain W-CI (Wang and Yeh 1998) were collected from Taiwan. P-YK systemically infects papaya, inducing leaf mosaic and stunting in growth; and cucurbits, causing leaf deformation, blistering, mosaic, yellowing and vein clearing. The virus elicits local lesions on Chenopodium quinoa Willd. Similarly, W-CI systemically infects cucurbits, causing leaf deformation, blistering, mosaic, yellowing, and vein clearing and elicits local lesions on Chenopodium quinoa. The major difference between W-CI and P-YK is that the former does not infect papaya. To investigate the viral genetic determinants for host preference and selectivity, in vitro and in vivo infectious cDNA clones of P-YK and W-CI were constructed as shown in Figure 1.

The in vitro capped transcripts of both pT3PYKF1 and pT3WCIF1 induced local lesions on Chenopodium quinoa and the above-described systemic symptoms on horn melon $\mathrm{Cucu}$ mis metuliferus (Naud.) Mey. (accession 2459). As expected, only the in vitro capped transcripts of pT3PYKF1-infected papaya plants, inducing mosaic symptoms. The transcripts induced host reactions similar to those induced by the corresponding wild-type viruses, except that the lesion development was delayed by 1 to 2 days. The viruses derived from the transcripts also showed host ranges similar to those of the respective wild-type viruses.

The constructs p35SPYK and p35SWCI, which could generate infectious viral transcripts in the host cell nuclei, induced symptoms similar to those induced by the wild-type P-YK and $\mathrm{W}-\mathrm{CI}$ viruses. However, the p35SPYK- and p35SWCI-induced symptoms were 2 to 3 days delayed than wild-type virusinduced symptoms. The papaya-infecting 35SPYK and nonpapaya infecting 35SWCI viruses derived from in vivo infectious clones of p35SPYK and p35SWCI, respectively, also induced host reactions similar to those induced by the respective wild-type viruses. All the generated viruses were verified by reverse transcription-polymerase chain reaction (RT-PCR) and enzyme-linked immunosorbent assay (ELISA).

\section{Confirmation of the construction}

of recombinant viruses in Cucumis metuliferus.

After verifying the identity and functioning of the parental clones of $\mathrm{P}-\mathrm{YK}$ and $\mathrm{W}-\mathrm{CI}$, nine recombinants were constructed by exchanging genomic segments between $\mathrm{P}-\mathrm{YK}$ and $\mathrm{W}-\mathrm{CI}$, as depicted in Figure 2A. The recombinant viruses P-WP3CP, PWCICP, P-WNIbCP, and W-PCINIa were generated by in vitro transcription of pT3P-WP3CP, pT3P-WCICP, pT3P-WNIbCP, and pT3W-PCINIa, respectively. Additionally, the recombinant viruses P-WCINIa, P-WCI6k, P-WNIa, W-PCI6k, and W-PNIa were generated from in vivo infectious clones of p35SPWCINIa, p35SP-WCI6k, p35SP-WNIa, p35SW-PCI6k, and p35SW-PNIa, respectively. All the constructed recombinant viruses were established in highly susceptible Cucumis metuliferus for confirming their identities and supplying viruses for further experiments. For confirmation of the identities of the recombinant viruses, the EcoRV $(4,346)$, SphI $(4,694)$, NheI $(7,147)$, and PstI $(8,176)$ restriction sites (positions of the sites, as nucleotide numbers, in parentheses) unique to the cDNA of P-YK (Fig. 2A) were analyzed. The genomic regions of the recombinants encompassing these contexts were amplified from the infected host plants by RT-PCR, and the presence or absence of the restriction sites were ascertained by appropriate restriction digestions. The restriction patterns conformed to the restriction maps of the clones (data not shown). Se- quencing of the RT-PCR products further confirmed the correct construction of the recombinants.

\section{Host reactions of recombinants on papaya.}

All the recombinant viruses systemically infected the plants of Cucumis metuliferus, inducing mosaic symptoms 6 to 8 days postinoculation (dpi) (Fig. 2A). However, only the recombinant viruses $\mathrm{P}-\mathrm{WNIbCP}, \mathrm{W}-\mathrm{PCINIa}, \mathrm{W}-\mathrm{PNIa}$, and PWCI6k were able to infect papaya plants (Fig. 2B). Of these papaya-infecting recombinant viruses, P-WNIbCP, W-PCINIa, and W-PNIa induced mosaic symptoms 10 to $14 \mathrm{dpi}$, while PWCI6k caused progressively lethal wilting on expanding leaves, leafstalks, and stems $21 \mathrm{dpi}$, though the initial symptom was mosaic (Fig. 2B). Unlike the wild type-like mosaic symptom induced by P-WNIbCP, the mosaic symptoms on the leaves of the plants infected by W-PCINIa and W-PNIa were interspersed with large green islands (Fig. 2B). Eventually, the infected plants recovered from the disease $30 \mathrm{dpi}$. During symptomatic phase, the plants infected by W-PCINIa and WPNIa showed virus accumulation (ELISA and RT-PCR data, not shown) lesser than the plants infected by the recombinant P-WNIbCP and the wild-type 35SPYK. After complete recovery $60 \mathrm{dpi}$, the recombinant viruses W-PCINIa and W-PNIa were not detected from the recovered plants (RT-PCR and ELISA data, not shown). Moreover, the viral inocula prepared from the recovered plants were not infective on healthy papaya plants.

The recombinant viruses P-WNIbCP, W-PCINIa, W-PNIa, and P-WCI6k, possessing the NsiI-SacI segment from the type $\mathrm{P}$ virus $\mathrm{P}-\mathrm{YK}$, induced symptoms on papaya. The identities of these papaya-infecting mutants were checked by sequencing their NsiI-SacI segment amplified by RT-PCR from papaya host. Conversely, the recombinant viruses P-WP3CP, PWCICP, P-WCINIa, P-WNIa, and W-PCI6k, possessing the NsiI-SacI fragment from the type $\mathrm{W}$ virus W-CI, did not induce symptoms on papaya 60 dpi (Fig. 2B). RT-PCR and ELISA were carried out to further confirm the recombinants that did not induce symptoms on papaya. From the symptomless papaya plants, no RT-PCR product was amplified and no positive ELISA signal was recorded. On the other hand, all the recombinants that induced symptoms on papaya could be readily detected by RT-PCR and ELISA (data not shown). The results of our recombination assays indicated that the PRSV genomic region of nt 6,509 to 7,700 of type P-YK, covering the coding sequence for the $142 \mathrm{C}$-terminal amino acids of NIaVPg and full NIaPro and the $18 \mathrm{~N}$-terminal amino acids of $\mathrm{NIb}$, was critical for papaya infection (Fig. 2A and B).

\section{Sequence comparison of genomic region critical for papaya infection.}

Amino-acid sequence comparison of nt 6,509 to 7,700 of the parental P-YK and W-CI showed variations at 10 amino-acid positions in the NIaVPg and NIaPro coding region (nt 6,509 to 7,643 ), as shown in Figure 3. However, the amino-acid sequence comparison of the same region from four type $\mathrm{P}$ and $\mathrm{W}$ viruses (i.e., P-YK [X97251], P-HA [S46722], W-CI [AY027810], and W-TH [AY010722], GenBank accession numbers in brackets) showed variations between type $\mathrm{P}$ and $\mathrm{W}$ viruses only at amino acid 176 of NIaVPg $(\mathrm{V} \rightarrow \mathrm{A}$, from type $\mathrm{P}$ to $\mathrm{W})$ and amino acids $27(\mathrm{~K} \rightarrow \mathrm{D})$ and $205(\mathrm{I} \rightarrow \mathrm{V})$ of NIaPro. Seven other amino acids that varied between P-YK and W-CI were not consistently different among these type $\mathrm{P}$ and $\mathrm{W}$ viruses.

\section{Host reactions of the point-mutation mutants.}

Amino-acid positions 176 of NIaVPg and 27 and 205 of NIaPro were selected for point mutations to further explore their possible roles in PRSV host-specificity. Single, double, 
A

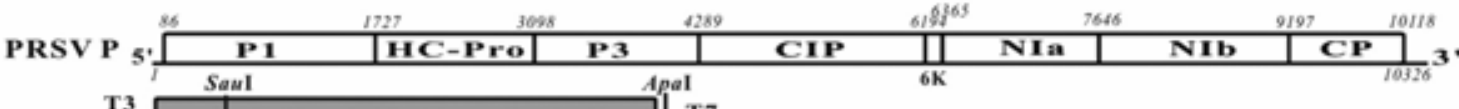

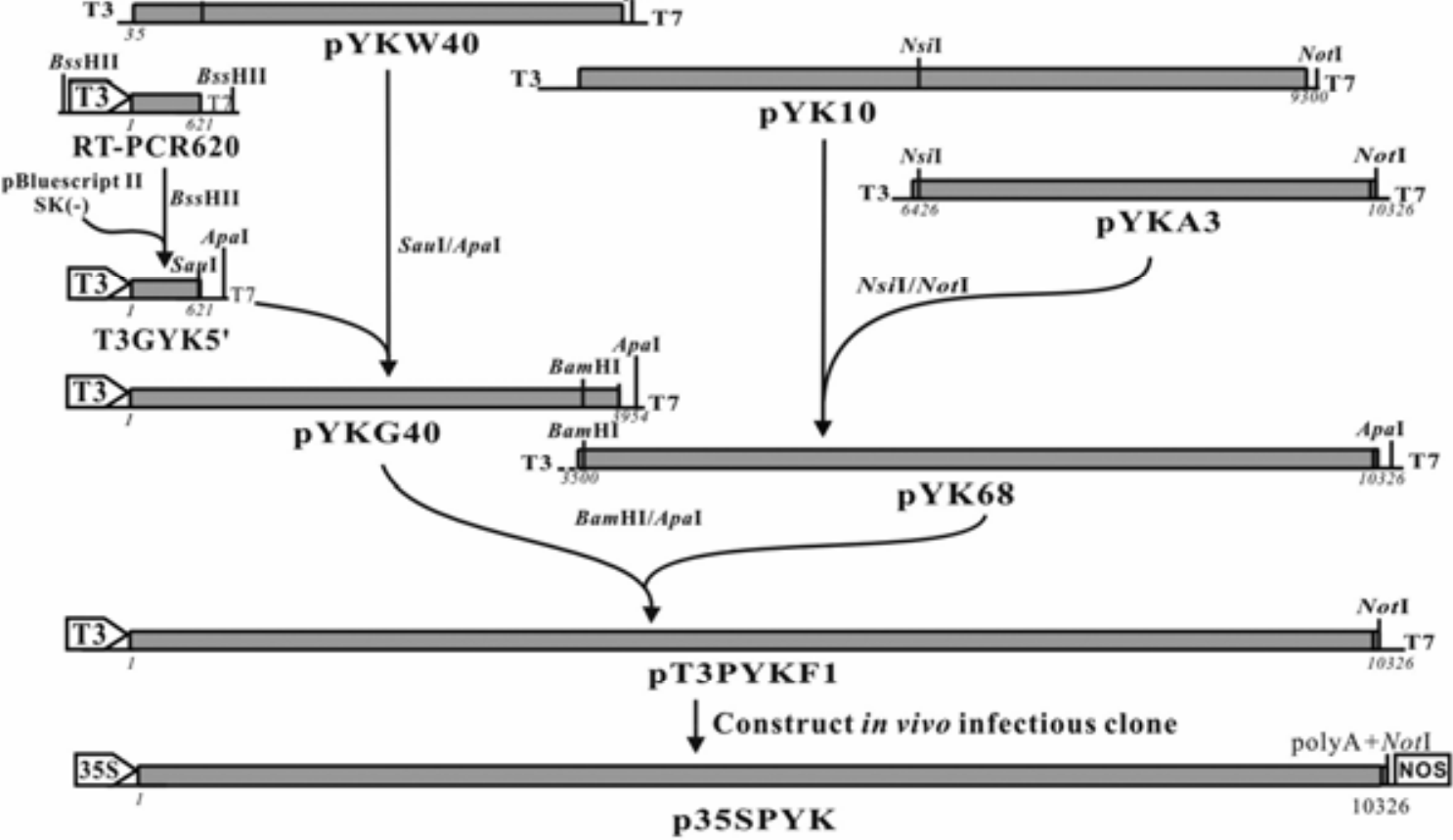

B

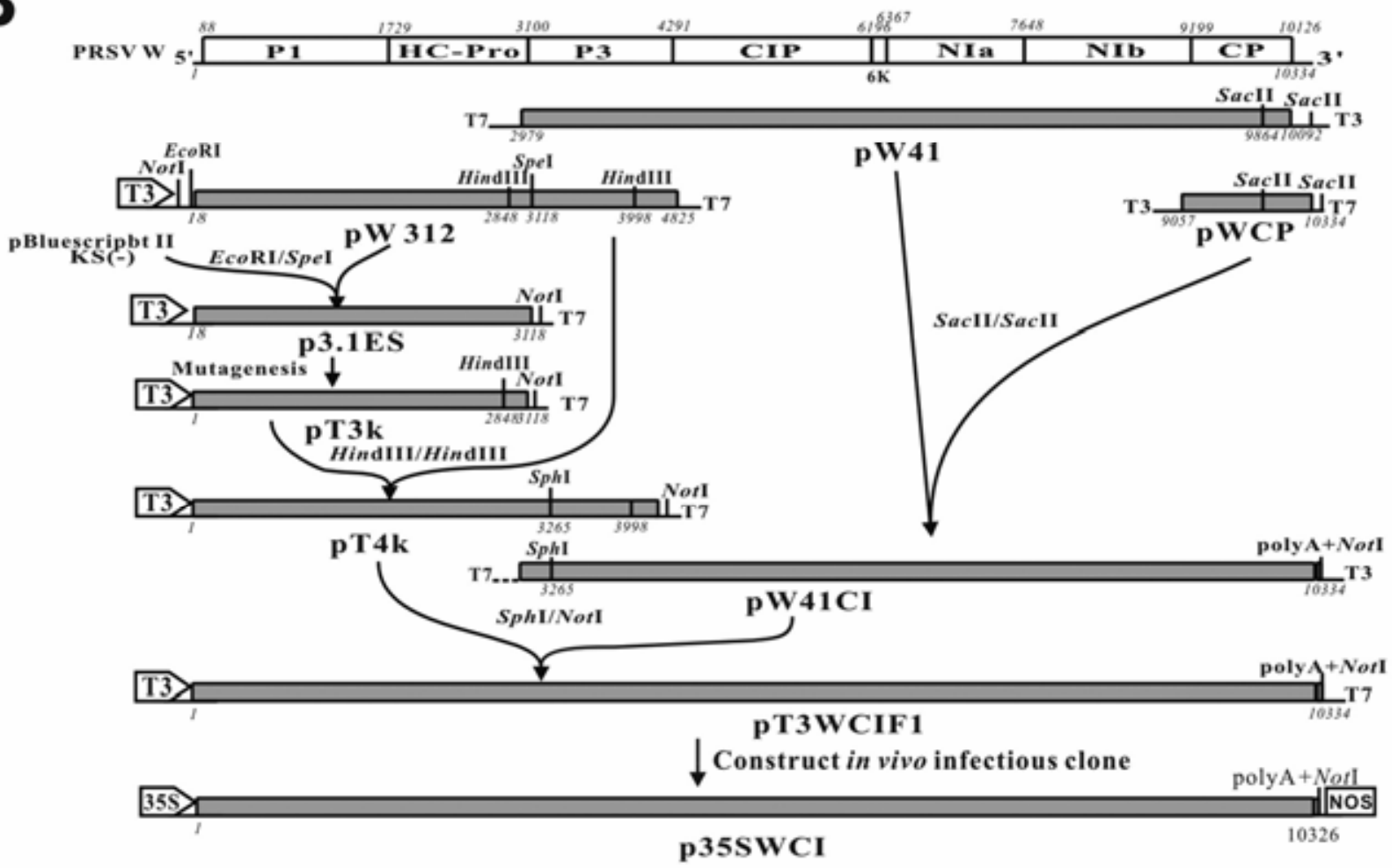

Fig. 1. Construction of infectious clones of two different types of Papaya ringspot virus (PRSV). A, Construction of infectious clones of a PRSV type P isolate P-YK. The cDNA of nucleotides 1 to 621 of P-YK genome with a T3 promoter was reverse transcription-polymerase chain reaction (PCR)-amplified and fused in appropriate order with restriction-derived $3^{\prime}$ genomic segments from pYK40, pYK10, and pYKA3 (obtained from a cDNA library) to generate pT3PYKF1 that generated the full-length infectious transcript of P-YK in vitro under the control of T3 promoter. Transfer of full-length P-YK cDNA from pT3PYKF1 to $\mathrm{pCaMVCN}$ by PCR and site-directed mutagenesis generated p35SPYK, which generated the infectious transcript of P-YK in vivo under the control of a $35 \mathrm{~S}$ promoter and a nos terminator. B, Construction of infectious clones of the PRSV type W isolate W-CI. The cDNAs of W-CI genomic segments released by restriction of pW312, pW41, and pWCP (obtained from a cDNA library) were used in appropriate order to generate pT3WCIF1 that generated the full-length infectious transcript of W-CI in vitro under the control of a T3 promoter. The nonviral sequence was removed, and the exact $5^{\prime} \mathrm{W}-\mathrm{CI}$ sequence was added by PCR-mutagenesis. Transfer of full-length W-CI cDNA from pT3WCIF1 to p35SWCI, which generated the infectious transcript of P$\mathrm{YK}$ in vivo under the control of $35 \mathrm{~S}$ promoter, was conducted as described for P-YK. 
and triple point mutations in the in vivo infectious clones of p35SPYK and p35SWCI were created. Seven P-YK mutant viruses and seven W-CI mutant viruses (Fig. 4) were introduced into Cucumis metuliferus and papaya plants. All the mutants induced systemic mosaic on Cucumis metuliferus plants, simi- lar to that induced by the parental wild-type viruses. Unlike wild-type P-YK, mutants P-YK(D), P-YK(AD), P-YK(DV), and $\mathrm{P}-\mathrm{YK}(\mathrm{ADV})$ did not induce symptoms on papaya plants. However, the mutants P-YK(A), P-YK(V), and P-YK(AV) induced mosaic symptoms on papaya plants similar to that

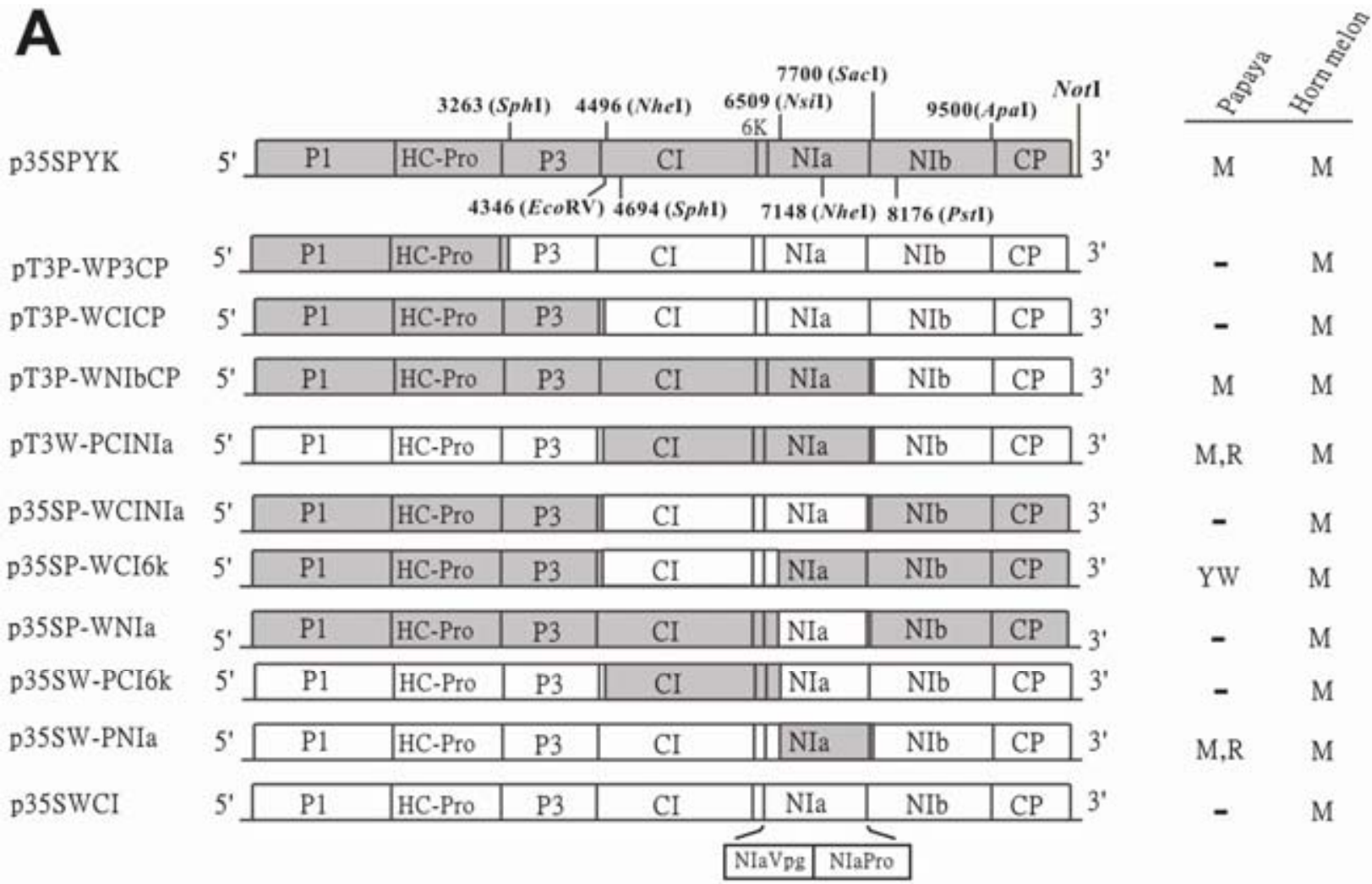
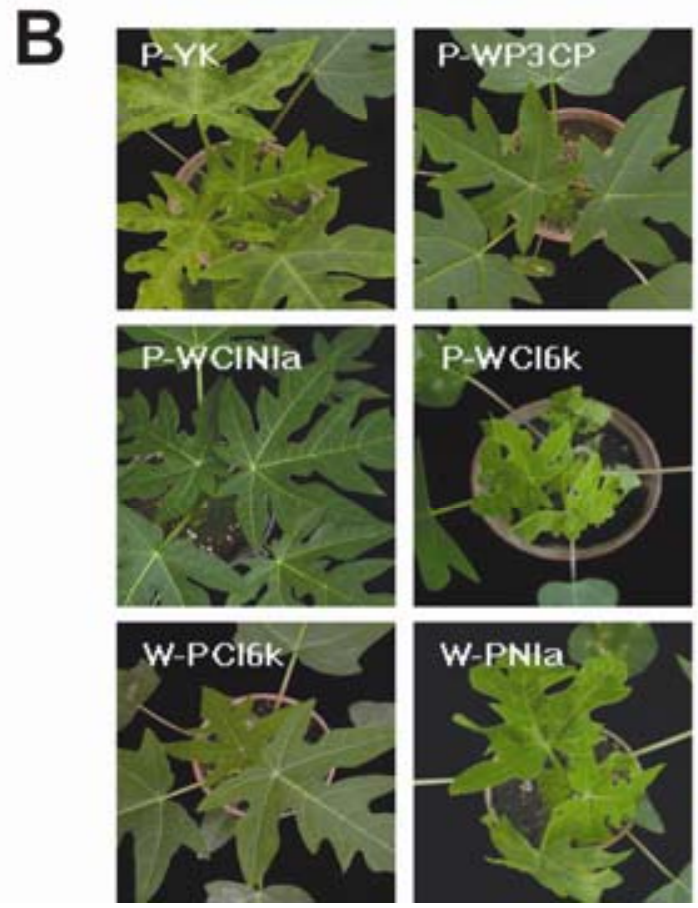
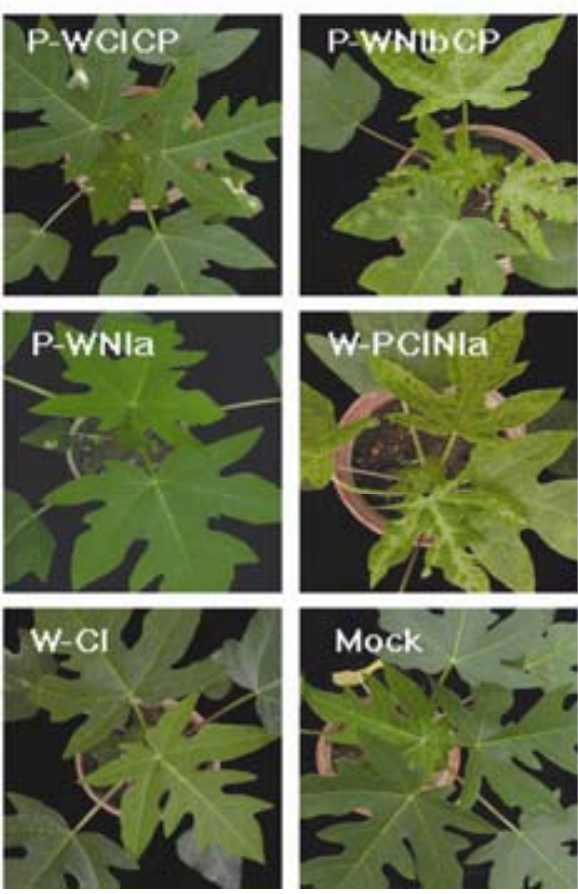
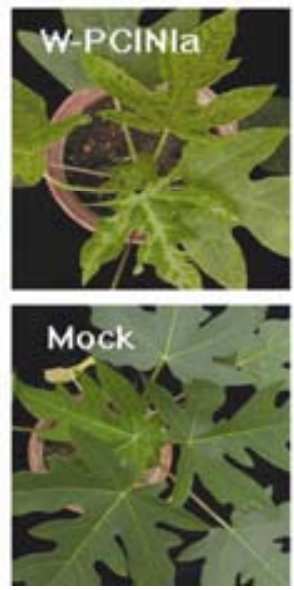

Fig. 2. The genetic organization and infectivity assay of recombinant viruses between Papaya ringspot virus (PRSV) P-YK and PRSV W-CI. A, In the recombinants, the gray regions represent the cDNA segments from P-YK and the blank regions represent the cDNA segments from W-CI. The restriction sites used for recombination are shown on p35SPYK carrying the cDNA of the P-YK genome. The parental and recombinant viruses were assayed on papaya plants by mechanical inoculation with respective plasmid constructs or in vitro transcripts. $\mathrm{M}=$ mosaic; $\mathrm{YW}=$ yellowing and wilting, $\mathrm{R}=$ recovery, and " - " $=$ no infection. B, Symptoms on papaya plants inoculated with P-WCI6k (14 dpi) and the other W-CI and P-YK recombinant viruses (21 dpi). Mock represents the plant inoculated with buffer. 
induced by $\mathrm{P}-\mathrm{YK}$. These results indicated that the change from $\mathrm{K}^{27} \rightarrow \mathrm{D}$ of NIaPro abolishes the ability of P-YK to infect papaya.

Among the W-type W-CI mutants, W-CI(K), W-CI(VK), W$\mathrm{CI}(\mathrm{KI})$, and $\mathrm{W}-\mathrm{CI}(\mathrm{VKI})$ were able to infect papaya (Fig. 4B). However, the symptoms caused by these mutants were slightly milder than those induced by W-PNIa and W-PCINIa (Fig. 2B), and the infected papaya plants eventually recovered from the symptoms $30 \mathrm{dpi}$. Thus, the results showed that the $\mathrm{D}^{27} \rightarrow \mathrm{K}$ change of NIaPro enables W-CI mutants to infect papaya plants and induce symptoms.

\section{Verification of papaya-infecting ability.}

Papaya infectivity of the site-specific mutants was verified by RT-PCR, ELISA, and Western blotting. The ELISA readings of papaya plants infected with the mutants $\mathrm{W}-\mathrm{CI}(\mathrm{K}), \mathrm{W}-\mathrm{CI}(\mathrm{VK})$, $\mathrm{W}-\mathrm{CI}(\mathrm{KI})$, and $\mathrm{W}-\mathrm{CI}(\mathrm{VKI})$, causing mild yellow spot or mosaic symptoms, were more than twofold when compared with that of the mock control (Fig. 5A). However, the intensities of Western blotting and RT-PCR signals of these plants were as low as 17 and $25 \%$, respectively, in comparison to those infected with P-YK, P-YK(A), P-YK(V), and P-YK(AV) (Fig. 5B and C). The immunosignals at positions smaller than that of $\mathrm{CP}$ from infected papaya plants was regarded as degraded forms of $\mathrm{CP}$ due to the cleavage by proteinases rich in papaya plants. Thus, the results of serological and molecular analyses corroborated the symptom observation of P-YK and W-CI mutants for papaya infection. These results verified that the changes from $\mathrm{K}^{27} \rightarrow \mathrm{D}$ and $\mathrm{D}^{27} \rightarrow \mathrm{K}$ of NIaPro are critical for non-papaya infecting and papaya-infecting abilities, respectively.

\section{Structural prediction of NIaPro of PRSV.}

The host reactions showed that the mutation at amino acid 27 of NIaPro was critical for papaya infection. To understand the location and protein environment of the critical amino acid in NIaPro and the possible effects of its mutations on the structure and electrostatic potential pattern of NIaPro, the three-dimensional (3-D) structures of NIaPros of P-YK and W-CI are necessary. Based on the crystal structure of NIaPro of Tobacco etch virus (TEV) (Protein data bank ID code 1LVB; Nunn et al. 2005), the 3-D structures of P-YK and W-CI NIaPros were predicted (Fig. 6) using the modeling package MODELLER (Lambert et al. 2002). Superimposition of the predicted 3-D structures of NIaPros of P-YK and W-CI on that of TEV revealed their similar structures. These structures revealed the location of the critical amino acid 27 on the surface of NIaPro. The Cys ${ }^{149}$-centered active site located at the interface of the domains of the two-domain antiparallel $\beta$-barrel fold structure of the protein was far away from amino acid 27 (Fig. 6).

\section{DISCUSSION}

The PRSV type P and W strains show definite host preferences on papaya (Caricaceae) and nonpapaya (Cucurbitaceae and Chenopodeace). However, they cannot be distinguished easily on the basis of genetic variations, and they tend to cluster on the basis of their geographical origin in phylogenetic analyses (Bateson et al. 1994, 2002; Chen et al. 2003; Davis and Ying 1999; Noa-Carrazana et al. 2006, 2007). These facts prompted the proposal that, in any geographical region, the PRSV type P strains originated indigenously from local type W strains by subtle genetic changes, mainly through mutations. In the present study, the criticality of amino acid 27 of NIaPro of PRSV for papaya infection was confirmed by the host switching of cucurbit-infecting W-CI to papaya, in which the NIaPro amino acid $\mathrm{Asp}^{27}$ alone was mutated to Lys. Our results demonstrated that residue variation in a single aminoacid position in NIaPro could determine selective or preferential infectivity of PRSV between systemic hosts belonging to two different plant families. Thus, our results provide direct experimental support to the hypothesis that the papaya-infecting PRSV type P viruses can evolve by mutation from PRSV type $\mathrm{W}$ viruses infecting the nonpapaya hosts.

It is conceivable that mutations that could alter host range may happen frequently in PRSV W populations, evolving papaya-infecting strains that establish in papaya plants (Bateson et al. 2002) and then devastate papaya production in an endemic manner. In papaya, the emerging virus population may gain fitness to infect papaya through selection, eventually losing its ability to infect cucurbits (Bateson et al. 2002), as supported by the rarity of natural infection of cucurbits by PRSV $\mathrm{P}$ (Gonsalves 1998) and difficulty in mechanical inoculation of
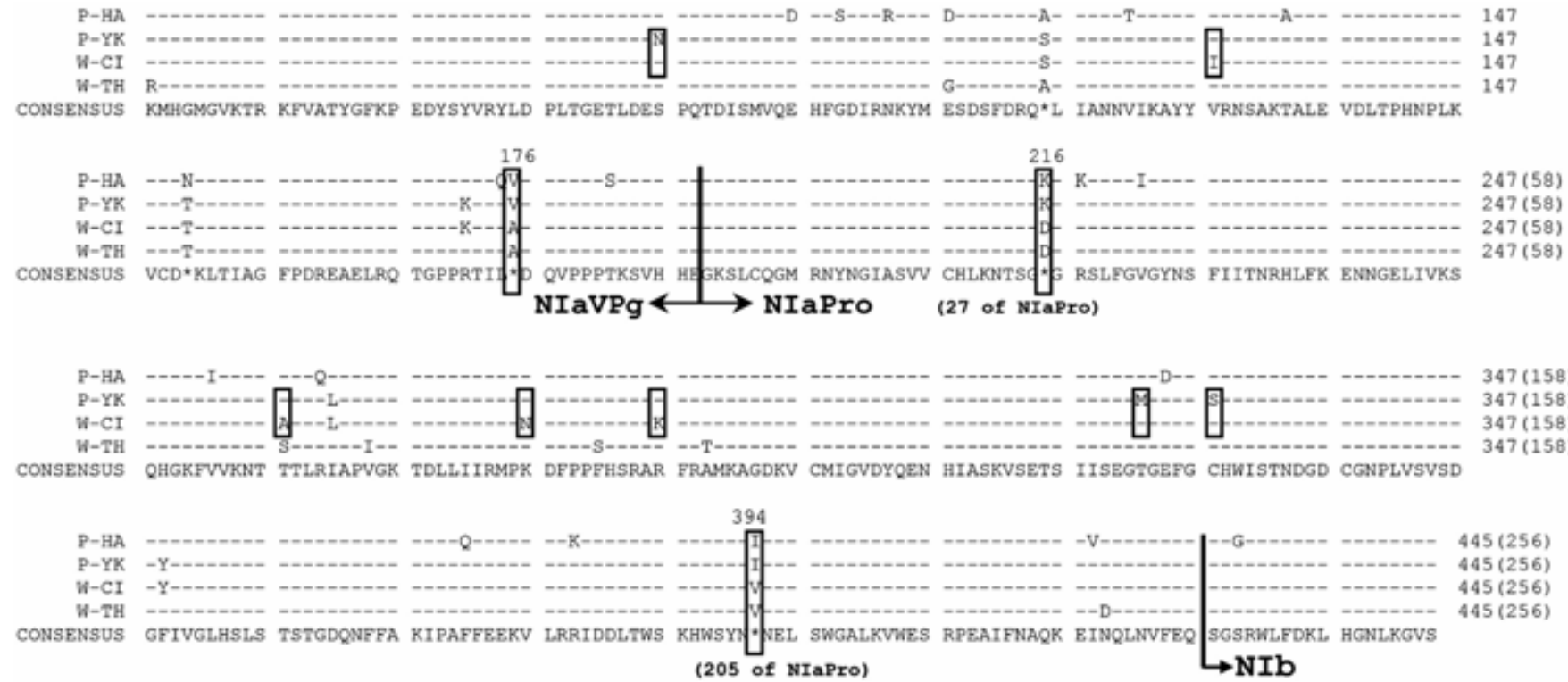

Fig. 3. The amino-acid sequence comparison of nucleotides 6,509 to 7,700 of two type P viruses (P-HA, and P-YK) and two type W viruses (W-CI, and W$\mathrm{TH})$. Three amino-acid variations in NIa, between two type $\mathrm{P}$ and two type $\mathrm{W}$ viruses, are indicated in long rectangles, under which the variations in NIaPro region of NIa are parenthesized. Seven other amino acids in NIa, differing only between P-YK and W-CI, are indicated in short rectangles. 
some PRSV P isolates on cucurbits (Yeh et al. 1984). Similarly, back-mutation of PRSV type P strains into type W ones can also take place.

The NIaPro of potyvirus is a major protease responsible for processing of the potyviral polyprotein (Carrington and Dougherty 1987; Riechmann et al. 1992; Urcuqui-Inchima et al. 2001). Mutations in NIaPro, which affect the structural characteristics of the protein, can profoundly influence the proteolytic specificity and efficiency of NIaPro (Tözsér et al. 2005) and affect the viral functions and existence (Mestre et al. 2000). In the present study, all the viruses mutated in NIaPro replicated and accumulated normally in Cucumis metuliferus, suggesting no debilitating influence of the mutated amino acids on the protease activity of NIaPro, though the mutation $\mathrm{D}^{27} \rightarrow \mathrm{K}$ of NIaPro caused a host-switching of PRSV from cucurbits to papaya. The protein-surface location of amino acid 27 and its distance from the Cys ${ }^{149}$-centered active site, situated at the interface of the domains of the two-domain antiparallel $\beta$-barrel fold structure (Fig. 6), further supported a remote possibility for amino acid 27 to influence protease activity of NIaPro. However, although the NIaPro $\mathrm{D}^{27} \rightarrow \mathrm{K}$ substitution does not seem to induce any significant change in the local

\begin{tabular}{|c|c|c|c|c|c|c|c|}
\hline \multirow[t]{3}{*}{ PRSV } & HC-Pro & P3 & $\mathrm{CI}$ & $\mathrm{NIa}$ & $\mathrm{NIb}$ & $\mathrm{CP}$ & $3^{\prime}$ \\
\hline & \multicolumn{4}{|c|}{ Amino acid position at $\mathrm{NIa}$ (at NIaPro) } & & \multicolumn{2}{|c|}{ Symptoms on } \\
\hline & 176 & & $216(27)$ & $394(205)$ & & $\underline{\text { Papaya }}$ & $\underline{\text { Horn melon }}$ \\
\hline$P-Y K$ & V & & $\mathrm{K}$ & I & & M & M \\
\hline$P-Y K(A)$ & A & & K & I & & M & M \\
\hline$P-Y K(D)$ & V & & D & I & & - & M \\
\hline $\mathrm{P}-\mathrm{YK}(\mathrm{V})$ & V & & K & V & & $\mathbf{M}$ & M \\
\hline$P-Y K(A D)$ & A & & D & I & & - & M \\
\hline$P-Y K(D V)$ & V & & D & V & & - & M \\
\hline$P-Y K(A V)$ & A & & $\mathrm{K}$ & v & & M & M \\
\hline$P-Y K(A D V)$ & A & & D & V & & - & M \\
\hline W-CI (V) & V & & D & $\mathrm{V}$ & & - & M \\
\hline$W-C I(K)$ & A & & $\mathrm{K}$ & V & & $\mathbf{M}, \mathbf{R}$ & M \\
\hline$W-C I(I)$ & A & & D & I & & - & M \\
\hline W-CI (VK) & V & & $\mathrm{K}$ & V & & $M, R$ & M \\
\hline$W-C I(K I)$ & A & & K & I & & $\mathrm{M}, \mathrm{R}$ & M \\
\hline$W-C I(V I)$ & V & & D & I & & - & M \\
\hline$W-C I(V K I)$ & V & & K & I & & $M, R$ & M \\
\hline$W-C I$ & A & & D & V & & - & M \\
\hline
\end{tabular}
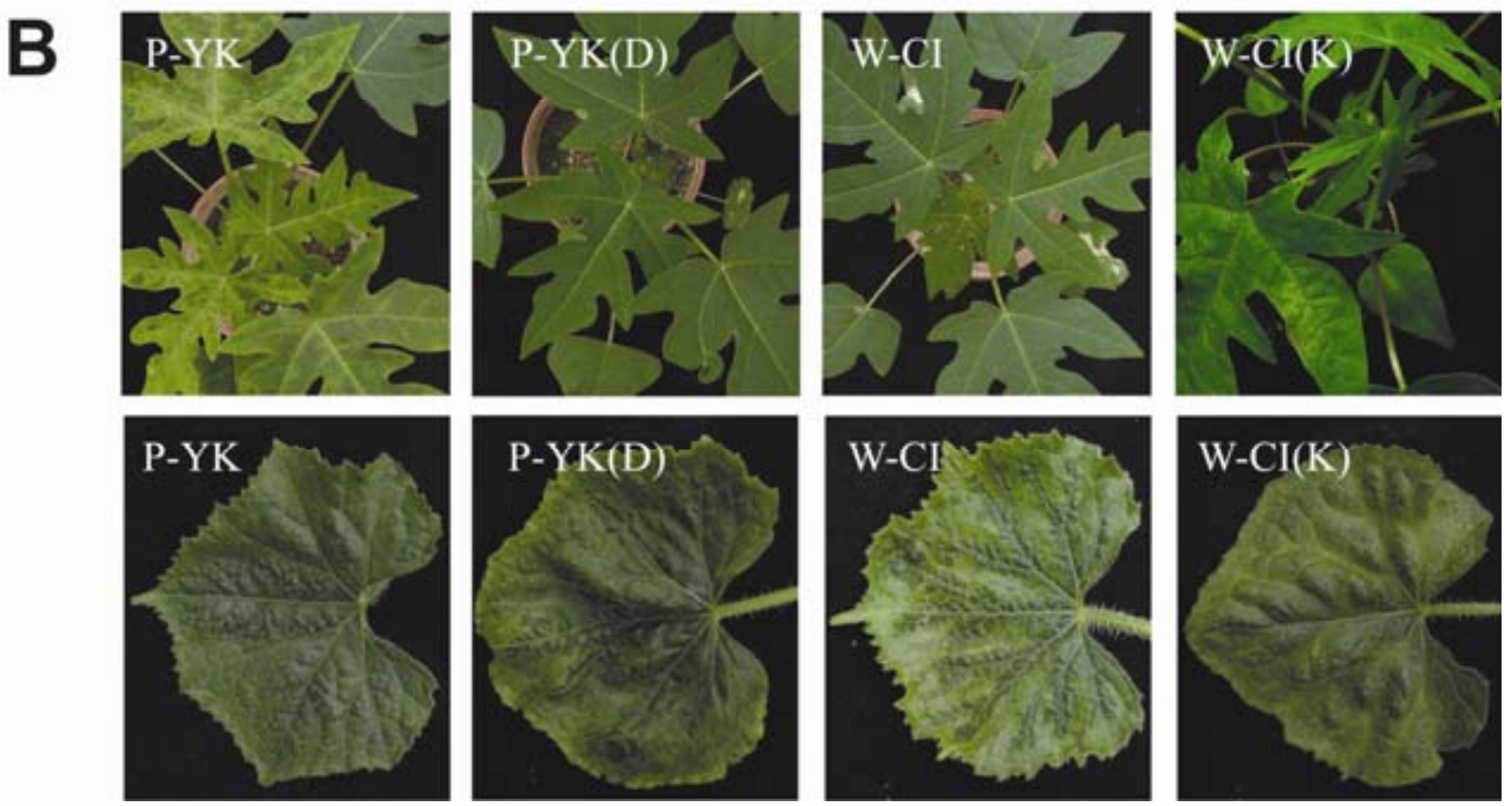

Fig. 4. Infectivity analyses of Papaya ringspot virus type $\mathrm{P}$ and $\mathrm{W}$ mutants. A, Characters in gray boxes denote the amino-acid residues mutated from $\mathrm{P}-\mathrm{YK}$ to W-CI or vice versa. The naked characters indicate amino-acid residues not mutated. $\mathrm{M}=$ mosaic symptoms; "-" = no infection; and $\mathrm{R}=$ symptom recovered. B, Symptoms on papaya and Cucumis metuliferus (horn melon) plants after infection with P-YK, PYK(D), W-CI, or W-CI(K). The upper panel row shows symptoms on papaya plants and the lower panel row shows symptoms on C. metuliferus (horn melon) plants. 
structure of the protein, this involves a reversal of charge from negativity to positivity and the emergence of a longer, flexible side chain at the position. Hence, despite the structurally assumed and functionally inferred lack of interference of amino acid 27 with NIa protease activity, mutation of this residue apparently has the potential to cause decisive changes in the interaction of NIaPro with certain papaya host factors as well as viral factors critical for papaya PRSV infection.

Potyvirus NIaPro exists not only as the fully processed protease but also as a domain of its precursors, NIaVPg-NIaPro and 6K-NIaVPg-NIaPro, involved in different essentially indispensable roles. Earlier, the interactions of the translation initiation factor eIF(iso)4E with NIaVPg-NIaPro and 6K-NIaVPg-
NIaPro localized, respectively, in the nucleolus and the vesicles associated with (or budding from) the endoplasmic reticulum (ER) (Beauchemin et al. 2007; Léonard et al. 2004) were demonstrated. The involvement of the nucleolus-localized complex of NIaVPg-NIaPro with eIF(iso)4E in disruption of host functions (to promote viral functions) and participation of the ER vesicle-localized complex of 6K-NIaVPg-NIaPro with eIF(iso)4E in viral replication (Beauchemin et al. 2007) were suggested. The interaction of eIF(iso)4E with the NIaVPgNIaPro precursors may be through the binding of eIF(iso)4E to the NiaVPg domain of these precursors, as supported by the previously reported close interaction of eIF(iso)4E with NIaVPg (Plante et al. 2004; Wittmann et al. 1997) and binding

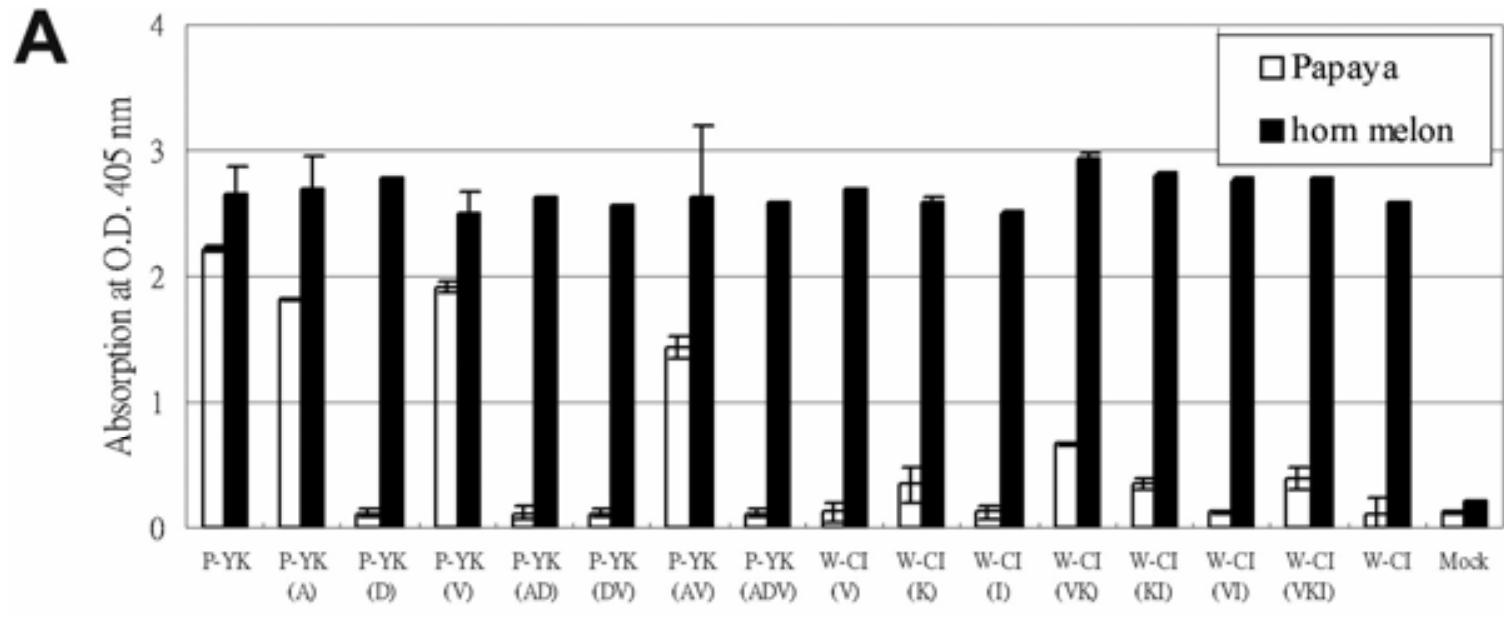

B
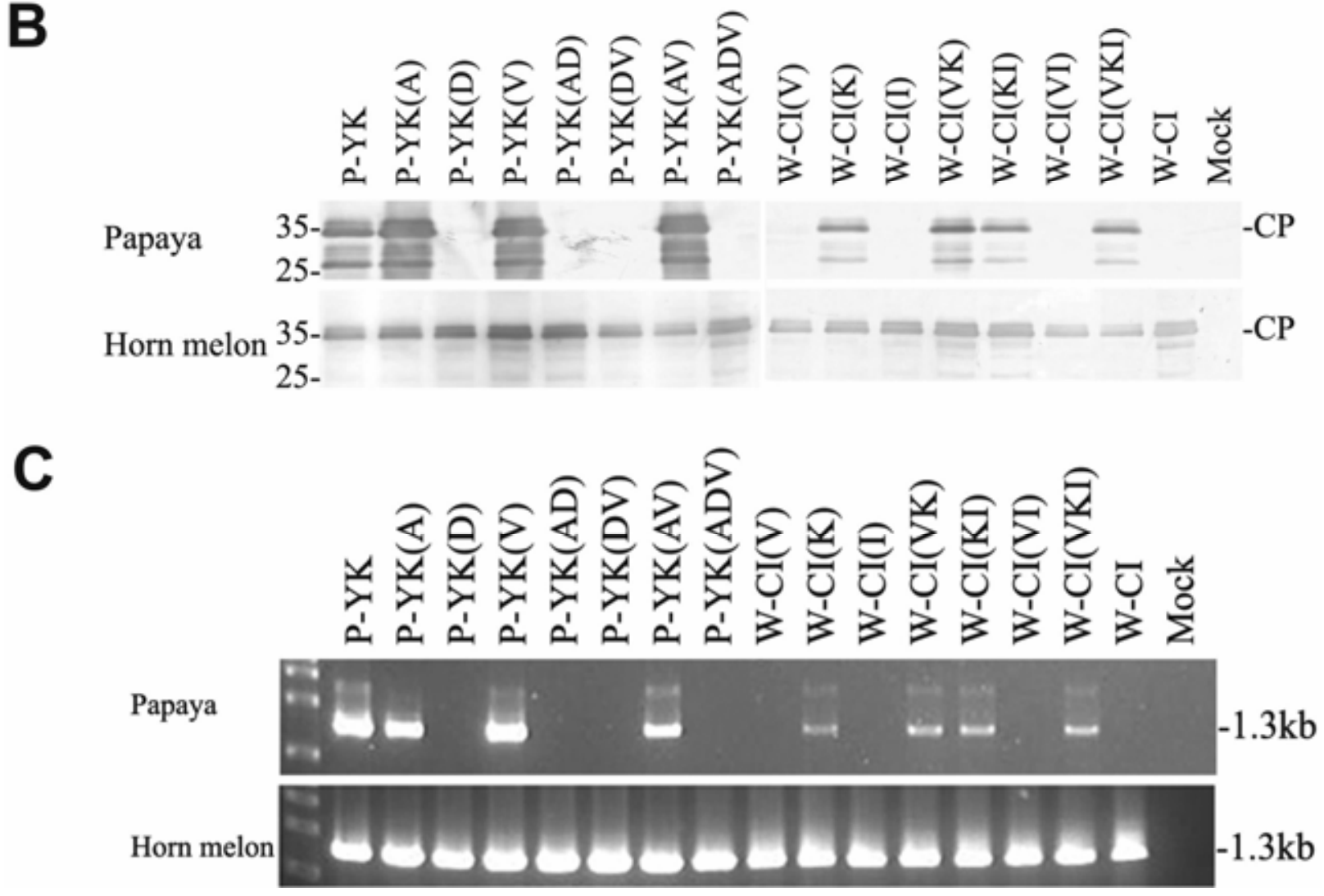

Fig. 5. Verification of papaya-infecting ability of Papaya ringspot virus (PRSV) type P and W mutant viruses with specific point mutations in NIa. A, Levels of accumulation of the mutant viruses in papaya and Cucumis metuliferus (horn melon) plants, as analyzed by enzyme-linked immunosorbent assay using the antiserum to PRSV. B, Detection of PRSV coat protein (CP) in the infected plants by Western blotting analysis using the antiserum to PRSV. The $35-\mathrm{kDa}$ immunosignal corresponding to PRSV CP is indicated. C, Reverse transcription-polymerase chain reaction analysis for the mutant viruses in the infected plants. The $1.3-\mathrm{kb}$ amplified product corresponding to nucleotides 6,365 to 7,645 of the PRSV genome is indicated. 
of eIF4E to the central domain NIaVPg (Roudet-Tavert et al. 2007). Mutations in the central domain of NIaVPg were correlated to breaking of host-resistance by several potyviruses, while those in eIF4E and eIF(iso)4E were correlated to emergence of host-resistance to potyviruses (Ayme et al. 2007; Robaglia and Caranta 2006; Yeam et al. 2007). These findings, together with the binding interaction of eIF4E or eIF(iso)4E with NIaVPg (Roudet-Tavert et al. 2007) as well as with the NiaVPg-NIaPro precursors (Beauchemin et al. 2007; Léonard et al. 2004), argue in favor of host resistance mediated by disruption or impairment of these interactions. Interestingly, our results demonstrated that NIaPro is a major infectivity factor for PRSV host specificity and that a critical mutation in NIaPro can dramatically affect PRSV-papaya interactions. It is possible that the break of PRSV incompatibility to papaya may be due to a possible effect of the mutation of amino acid 27 of the NIaPro-domain of 6K-NIaVPg-NIaPro on the adjacent eIF4E- or eIF(iso)4E-interacting NIaVPg domain. Involvement of $6 \mathrm{~K}-\mathrm{NIaVPg}-\mathrm{NIaPro}$ in potyvirus replication was suggested previously (Beauchemin et al. 2007; Schaad et al. 1997).

Alternatively, the NIaPro mutation may affect the crucial interaction of NIb, which codes for the viral RNA-dependent
RNA polymerase. In TEV replication, the trans-active nature of NIb and its recruitment to replication complexes (Hong et al. 1995; Li and Carrington 1995) and its specific physical interaction with NIaPro (Hong et al. 1995; Li et al. 1997) were shown. This interaction, which can be disrupted or impaired by mutations in several regions of NIb, can adversely affect TEV replication (Li et al. 1997).

In PRSV, the possible involvement of other viral proteins in enhancing its virulence and adaptation to papaya was implied by the present results. The recovery of the plants from symptoms induced by the recombinant viruses W-PCINIa and WPNIa and the nonrecovery of those infected by P-WNIbCP suggested the importance of certain determinants in the viral genomic region encoding P1-HCPro-P3 of P-YK for the establishment of the virus in papaya, preventing host recovery. Of these three recombinant viruses, only $\mathrm{P}-\mathrm{WNIbCP}$ possessing P1-HCPro-P3 of P-YK accumulated in papaya to a level comparable to the wild-type P-YK. Similarly, Salvador and associates (2008) suggested the existence of important genetic determinants in P1, HCPro, and P3 underlying host-specific pathogenicity and adaptation of Plum pox virus.

The influence of $\mathrm{CI}$ and $6 \mathrm{~K}$ in the virulence of PRSV in papaya was suggested by the recovery of the infected plants

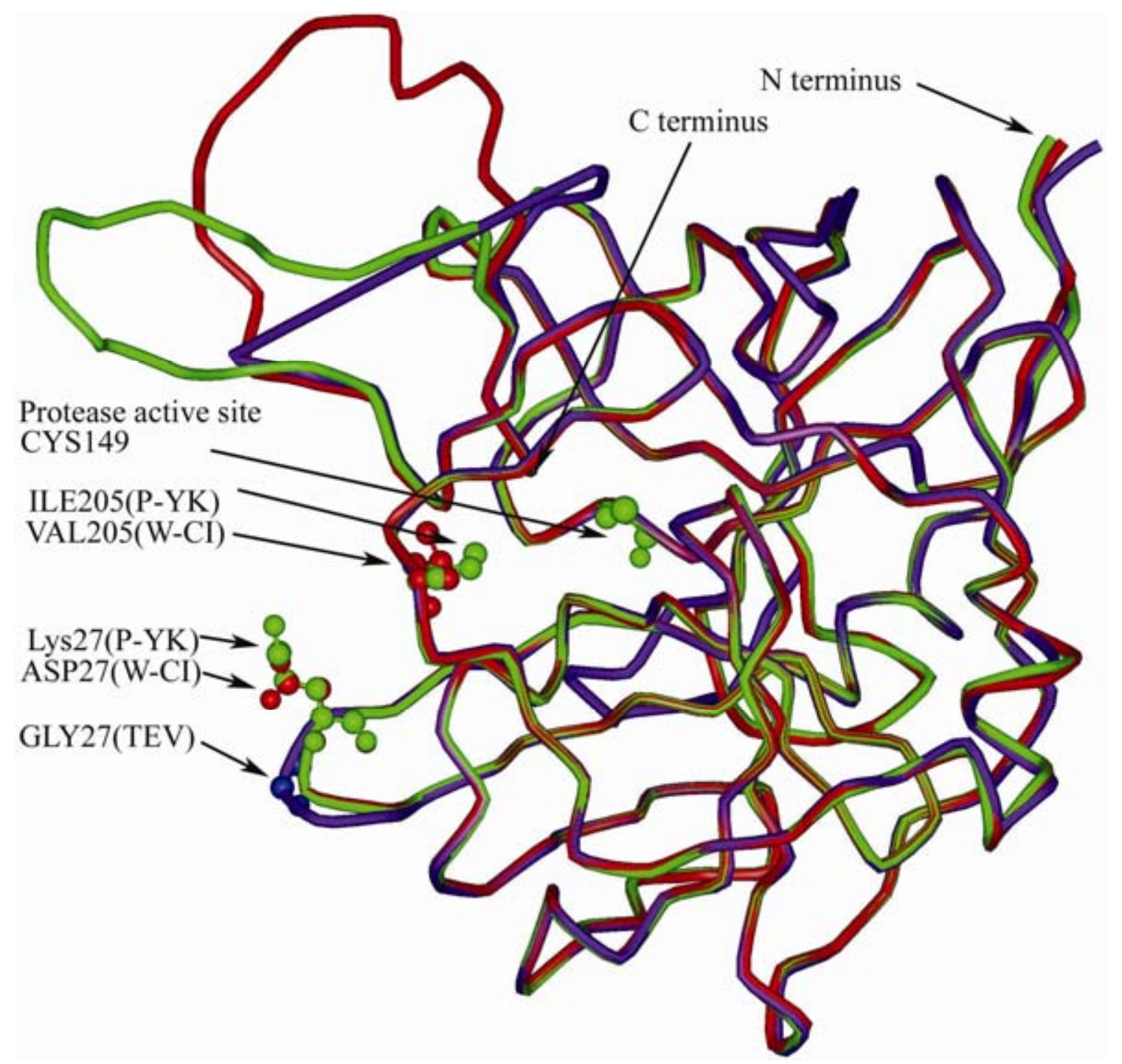

Fig. 6. Superimposition of the three-dimensional structures of the NIaPros of Papaya ringspot virus P-YK, W-CI, and Tobacco etch virus (TEV). The blue, yellow, and red colors represent TEV, P-YK, and W-CI NIaPro, respectively. The Cys ${ }^{149}$ of the NIaPro active site and the critical amino-acid positions Lys ${ }^{27}$ (P-YK), $\mathrm{Asp}^{27}$ (W-CI), and Gly ${ }^{27}$ (TEV) are indicated. The unimportant amino-acid positions $\mathrm{Ile}^{205}$ (P-YK) and Val ${ }^{205}$ (W-CI) are also indicated. 
from the milder symptoms induced by the recombinant virus $\mathrm{W}$-PNIa and the mutant viruses W-CI (K), W-CI(VK), W$\mathrm{CI}(\mathrm{KI})$, and W-CI(VKI) (Fig. 4) and the fatal wilting of those infected by P-WCI6k. The wilting symptom induced by $\mathrm{P}$ WCI6k was similar to that induced by a previously described wilting pathotype of PRSV (Chang 1979) that induced fast wilting leading to death. Prior to wilting however, P-WCI6k induced yellowing rather than vein-clearing symptoms, as described by Chang (1979). On the other hand, the recombinant virus W-PNIa, expressing the type $\mathrm{W}$ versions of $\mathrm{CI}$ and $6 \mathrm{~K}$, infected papaya plants without causing wilting symptoms. This suggested that the wilting symptoms induced by P-WCI6k resulted from possible interactions of $\mathrm{CI}$ and $6 \mathrm{~K}$ of W-CI with one or more specific proteins of P-YK. Chu and associates (1997) reported that the P3, CI, 6K, and NIaVPg of TEV were responsible for root necrosis leading to wilting symptoms in tabasco pepper plants. However, obviously, the presently observed wilting symptoms of the top leaves, in which the interactions of PRSV type $\mathrm{W}$ CI and $6 \mathrm{~K}$ proteins with certain PRSV type P proteins were implicated, was not due to root necrosis. This symptom might be the result of a possible systemic hypersensitive reaction of papaya against P-WCI6k.

The recombinant viruses, W-PCINIa and W-PNIa and the mutant viruses $\mathrm{W}-\mathrm{CI}(\mathrm{K}), \mathrm{W}-\mathrm{CI}(\mathrm{VK}), \mathrm{W}-\mathrm{CI}(\mathrm{KI})$, and $\mathrm{W}$ $\mathrm{CI}(\mathrm{VKI})$ infected papaya and induced mosaic symptoms. Their accumulation in papaya was lesser than the other papaya-infecting mutant viruses P-YK(A), P-YK(V), and P-YK(AV), and the infected plants recovered $30 \mathrm{dpi}$. The lesser accumulations of the mutants in the host might be because of ineffective suppression of host defense by these mutants, though they initiated virus-induced gene silencing (VIGS) (Lu et al. 2003). The undetectability of the mutant viruses in the recovered plants and the nonelicitation of cross protection against the severe strain P-YK suggested that VIGS was not maintained in these plants. However, the parental P-YK and its papaya-infecting mutants $[\mathrm{P}-\mathrm{YK}(\mathrm{A}), \mathrm{P}-\mathrm{YK}(\mathrm{V})$, and $\mathrm{P}-\mathrm{YK}(\mathrm{AV})]$ were able to suppress VIGS in papaya. When the recovered plants were challenged with P-YK, they developed systemic mosaic symptoms (data not shown).

Although the present results strongly suggest NIaPro as the major host-specificity determinant of PRSV, the mechanism that blocks the papaya-infecting ability of PRSV W is yet to be elucidated. Though the present data implies that the inability of PRSV W to infect papaya may be due to its inability to replicate in the host, its limitations in effecting cell-to-cell movement or long-distance translocation may also be the other causes. Alternatively, the virus may be able to induce a subliminal hypersensitive reaction in papaya without explicit symptoms. To address these questions, it is necessary to examine the ability of the type $\mathrm{W}$ virus to replicate in the protoplasts of papaya and perform cell-to-cell movement and translocation. Since papaya protoplast culture is not available, efforts are on the way to establish a papaya protoplast assay system.

\section{MATERIALS AND METHODS}

Virus sources.

Two PRSV strains used in this study, P-YK and W-CI, were collected from Taiwan. P-YK is a mosaic strain of PRSV type $P$ virus, collected from infected papaya in Yung-kung, Tainan County (Wang and Yeh 1997). W-CI is a strain of PRSV type W virus collected from luffa gourd (Luffa cylindrica $\mathrm{M}$. Roem.) in Chia-yi (Wang and Yeh 1998). Their full-length sequences were determined previously (GenBank accession numbers X97251 and AY027810 for P-YK and W-CI, respectively). Both P-YK and W-CI were maintained in plants of $\mathrm{Cu}$ cumis metuliferus, following mechanical transfer.

\section{Construction of in vitro infectious clones of PRSV P-YK and W-CI.}

Virus purification, viral RNA preparation, cDNA synthesis, cloning, and nucleotide sequencing of complete genomic RNA of PRSV P-YK or W-CI were carried out as described previously (Yeh et al. 1992). The primers used in the construction

Table 1. Oligonucleotide primers used in this study

\begin{tabular}{|c|c|c|c|c|}
\hline Aim & Name & Sequences $\left(5^{\prime} \text { to } 3^{\prime}\right)^{a}$ & Polarity $^{b}$ & $\begin{array}{c}\text { Restriction } \\
\text { enzyme }\end{array}$ \\
\hline \multirow[t]{7}{*}{ Infectious clone } & MYK858N & TCGCGGCCGCTTTGAGGAACTGTACTTGT & - & Not $\mathrm{I}$ \\
\hline & P35SPYK20 & GTTCATTTCATTTGGAGAGGAAATAAAACATCTCAACACA & + & \\
\hline & P35SWCI36 & ATTTCATTTGGAGAGGAAAAATAAAACATCTCAACACAACACAATTCAAAGC & + & \\
\hline & PSWCI22 & CCGTCGACAAAAATAAAACATCTCCAACACA & + & \\
\hline & T3G22 & AAGCGCGCAATTAACCCTCACTAAAGAAAAATAAAACATCTCAACACA & + & BssHII \\
\hline & T3G36 & 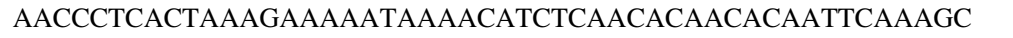 & + & \\
\hline & YKT7602 & GAGCGCGCGTAATACGACTCACTATAGGGCCCATCTCAGGCTCCTCAGGTGC & - & BssHII \\
\hline \multirow[t]{8}{*}{ RT-PCR } & MPYKX7643 & GGCTCGAGTTGTTCAAAAACATTCAATTG & - & XhoI \\
\hline & MWCIX7645 & GGETCGAGTTGCTCAAAAACGTTCAATTG & - & XhoI \\
\hline & MWM2S5014 & ACTATTCGCACCAGTACCGAAATTG & - & \\
\hline & MWM4S8991 & GCCACGATTCTTTCAGGTTCAAG & - & \\
\hline & PWCIE6365 & GGAATTCGGTTTCTCCGCGCGGCAGC & + & EcoRI \\
\hline & PWM6956 & AGGAATTACAATGGCATAGC & + & \\
\hline & PYK3153 & AAGCCTCATGAACTCCGCAATC & + & \\
\hline & PYKE6363 & GGAATTCGGTTTCTCCGCGCGACAGC & + & EcoRI \\
\hline \multirow[t]{12}{*}{ Point-mutation } & MP176A & GAACTTGGTCCGCCAAAATTG & - & AvaII \\
\hline & MP216D & CAAGCTTCGGCCGTCCCCTGACGTG & - & EagI \\
\hline & MP394V & CCAGCTCAATTCATTGACATTGTAGCTCCAGT & - & Loss $S s p \mathrm{I}$ \\
\hline & MW176V & GACTTGGTCGACCAAAATTG & - & SalI \\
\hline & MW216K & CTCCAAATAAGG $\overline{A C C G T C C T T T C C C T G A C G T G ~}$ & - & AvaII \\
\hline & MW394I & CCAGCTCAATTCATT $\underline{A A T A T T G T A G C T C C A G T G ~}$ & - & SspI \\
\hline & PP176A & CAATTTTGGCGGACCAAGTTC & + & AvaII \\
\hline & PP216D & CACGTCAGGGGACGGCCGAAGCTTG & + & EagI \\
\hline & PP394V & CACTGGAGCTACAATGTCAATGAATTGAGCTGG & + & Loss $S s p \mathrm{I}$ \\
\hline & PW176V & CAATTTTGGTCGACCAAGTC & + & SalI \\
\hline & PW216K & CACGTCAGGGAAAGGACGGTCCTTATTTGGAG & + & AvaII \\
\hline & PW394I & CACTGGAGCTACAATATTAATGAATTGAGCTGG & + & SspI \\
\hline
\end{tabular}

${ }^{a}$ Underlined bases indicate restriction sites and italicized-bold bases represent mutated nucleotides.

${ }^{\mathrm{b}}$ Polarity to Papaya ringspot virus RNA. 
are listed in Table 1. The strategy for construction of in vitro infectious cDNA clone of PRSV P-YK is summarized in Figure $1 \mathrm{~A}$. The cDNA segment reflecting nt 1 to 621 of the viral genome was amplified by RT-PCR with the reverse primer YKT7602 (with a BssHII site, a T7 promoter, an ApaI site, and nt 621 to 602 of the viral RNA) and the forward primer T3G22 (with a BssHII site, a T3 promoter, and the first 22 nt of the viral RNA). The amplified fragment was cloned in pCR2.1TOPO (Invitrogen, Carlsbad, CA, U.S.A.) to generate pRTPCR620. The BssHII fragment released from pRT-PCR620 was further cloned in pBluescript II $\mathrm{SK}(-)$ to generate pT3GYK5' (Stratagene, La Jolla, CA, U.S.A.). The constructs pYK40, pYK10, and pYKA3 (obtained from a cDNA library; Wang and Yeh 1997) carrying cDNA versions of different regions of the P-YK genome were restricted with appropriate restriction enzymes, and the required $\mathrm{P}-\mathrm{YK}$ genomic regions were ligated with pT3GYK5' to generate pT3PYKF1 that could generate in vitro the full-length infectious transcript of P-YK under the control of the T3 promoter (Fig. 1A).

The strategy for the construction of the in vitro infectious cDNA clone of PRSV W-CI is presented in Figure 1B. The constructs, pW312, pW41, and pWCP (obtained from a cDNA library constructed as described by Wang and Yeh 1997) carrying cDNA versions of different regions of W-CI genome were used for the present construction. The EcoRI-SpeI fragment representing nt 18 to 3,118 of $\mathrm{W}$-CI released from $\mathrm{pW} 312$ was first cloned in pBluescript II KS(-) to generate p3.1ES. The 66-nt polylinker portion of pBluescript II KS(-) intervening the $\mathrm{T} 3$ promoter and the $5^{\prime}$ portion of $\mathrm{W}-\mathrm{CI}$ cDNA in $\mathrm{p} 3.1 \mathrm{ES}$ was removed, and the first $17 \mathrm{nt}$ of the $5^{\prime}$ terminus of $\mathrm{W}-\mathrm{CI}$ were added by site-directed mutagenesis using the GeneEditor in vitro site-directed mutagenesis system (Promega, Madison, WI, U.S.A.) with the primer T3G36 (representing $14 \mathrm{nt}$ of the T3 promoter and the first $36 \mathrm{nt}$ of $\mathrm{W}-\mathrm{CI}$ cDNA) to generate pT3k. Required W-CI cDNA portions released from the constructs pW312, pW41, and pWCP by appropriate restrictions were ligated with pT3k to generate pT3WCIF1 that could generate in vitro the full-length infectious transcript of W-CI.

\section{Construction of in vivo infectious clones of PRSV P-YK and W-CI.}

For construction of the in vivo infectious clone of $\mathrm{P}-\mathrm{YK}$, the cDNA representing nt 1 to 854 of the P-YK genome was amplified from pT3YKFN1, with the forward primer PSWCI22 and the reverse primer MYK858N possessing a Not I site at the $5^{\prime}$ end. The amplified fragment was cloned into pCR2.1TOPO (Invitrogen) and was then transferred to pCaMVCN (Pharmacia/LKB, South Plainfield, NJ, U.S.A.), possessing a Cauliflower mosaic virus $35 \mathrm{~S}$ promoter and a nos terminator, to generate pCaMVP5. The 71-nt intervening sequence between the $35 \mathrm{~S}$ promoter and the $5^{\prime}$ end of P-YK cDNA in pCaMVP5 was removed by site-directed mutagenesis (Promega) with the oligonucleotide P35SPYK20 representing the last $20 \mathrm{nt}$ of the $35 \mathrm{~S}$ promoter and the first $20 \mathrm{nt}$ of P-YK cDNA. The Bsu36I-NotI fragment released from the mutated construct was ligated to pT3YKF1, restricted by the same enzymes, to obtain the final construct of p35SPYK possessing a full-length cDNA of P-YK under the control of the $35 \mathrm{~S}$ promoter and nos terminator (Fig. 1A), to generate the viral transcript in vivo.

The strategy for the construction of the in vivo infectious clone of W-CI was similar to the above-described construction of p35SPYK. The oligonucleotide P35SWCI36 was used for the removal of the 71-nt nonviral sequence between the $35 \mathrm{~S}$ promoter and the $5^{\prime}$ end of W-CI cDNA in pCaMVW5 carrying the $5^{\prime}$ portion of $\mathrm{W}-\mathrm{CI}$ cDNA. After the removal of nonviral sequence, the AgeI-NotI fragment released from the con- struct was ligated with pT3WCIF1 restricted by the same enzymes to obtain the final construct of p35SWCI possessing the full-length cDNA of W-CI under the control of the $35 \mathrm{~S}$ promoter and nos terminator (Fig. 1B), to generate the viral transcript in vivo.

\section{Synthesis of infectious transcripts and infectivity assay.}

Synthesis of infectious in vitro transcripts of the parental, recombinant, and mutant viruses and their mechanical inoculation on host plants were performed as described previously (Chiang and Yeh 1997). The in vitro transcription was carried out using the mCAP mRNA capping kit (Stratagene) to generate capped transcripts. The in vitro transcription products of the viral constructs ( 1 to $2 \mu \mathrm{g}$ of RNA in $40 \mu \mathrm{l}$ ) were mechanically applied with a pair of sterilized glass spatulas, onto two Carborundum-dusted leaves of papaya seedlings at four-trueleaf stage, the local lesion host Chenopodium quinoa plants at the eight-fully expanded-leaf stage, and Cucumis metuliferus at two-true-leaf stage. Similarly, the infectivity assays of in vivo infectious viral constructs were performed by mechanical inoculation of individual plasmids onto two Carborundumdusted leaves of papaya, Chenopodium quinoa, and Cucumis metuliferus plants.

\section{Construction of recombinant viruses.}

The in vitro or in vivo infectious clones of P-YK and W-CI were used for the construction of different recombinants by exchanging genomic parts the two viral cDNAs by restriction digestions at the same positions and subsequent ligations. The sites for restriction enzymes, SphI, NheI, NsiI, and SacI, were selected for recombination of infectious cDNAs of P-YK and W-CI. Recombinants possessing heterologous cDNA regions are shown in Figure 2A.

\section{Sequence analysis.}

The PRSV genomic region of nt 6,509 to 7,700 showing pathotype-related sequence variations were analyzed by the GCG software Pretty program (Wisconsin Package Version 10.0, Genetics Computer Group, Madison, WI, U.S.A.). In the present sequence analysis, the polyprotein sequences of all the GenBank-available PRSV type $\mathrm{P}$ and $\mathrm{W}$ were used, including those of P-YK (X97251) from Taiwan and P-HA (S46722) from Hawaii, W-CI (AY027810) from Taiwan and W-TH (AY010722) from Thailand (GenBank accession numbers in parenthesis).

\section{Point mutations in NIa regions of type $P$ and $W$ viruses.}

Specific mutations were performed on in vivo infectious clones p35SPYK and p35SWCI, using the QuikChange XL site-directed mutagenesis kit (Stratagene). Three primer pairs, MP176A and PP176A, MP216D and PP216D, and MP394V and PP394V (Table 1), were used for inducing single-, double-, or triple-point mutations to create type $\mathrm{W}$ residues at critical positions of NIaVPg $(176 \mathrm{~V} \rightarrow \mathrm{A})$ and NIaPro $(27 \mathrm{~K} \rightarrow \mathrm{D}$ and $205 \mathrm{I} \rightarrow \mathrm{V}$ ) of P-YK. To confirm the identity of the resultant mutants, suitable restriction sites were introduced in or abolished from the mutants. In the P-YK mutants, AvaII and EagI sites were introduced at positions 176 of NIaVPg and 205 of NIaPro, and the existing $S s p I$ site was abolished from position 205 of NIaPro. Similarly, another three primer pairs, MW176V and PW176V, MW216K and PW216K, and MW394I and PW394I (Table 1), were used for inducing single-, double-, or triple-point mutations to create type $\mathrm{P}$ residues at critical positions of NIaVPg $(176 \mathrm{~A} \rightarrow \mathrm{V})$ and NIaPro $(27 \mathrm{D} \rightarrow \mathrm{K}$ and 205 $\mathrm{V} \rightarrow \mathrm{I})$ of W-CI. In the W-CI mutants, SalI, AvaII, and SspI sites were introduced at positions 176 of NIaVPg and 27 and 205 of NIaPro, respectively. Seven P-YK mutated constructs 
were made to generate single-mutants $\mathrm{P}-\mathrm{YK}(\mathrm{A}), \mathrm{P}-\mathrm{YK}(\mathrm{D})$, and P-YK(V), double-mutants P-YK(AD), P-YK(DV), and P$\mathrm{YK}(\mathrm{AV})$, and triple-mutant P-YK(ADV) (Fig. 4A). Seven WCI mutated constructs were made to generate single-mutants $\mathrm{W}-\mathrm{CI}(\mathrm{V}), \mathrm{W}-\mathrm{CI}(\mathrm{K})$, and $\mathrm{W}-\mathrm{CI}(\mathrm{I})$, double-mutants $\mathrm{W}-\mathrm{CI}(\mathrm{VK})$, $\mathrm{W}-\mathrm{CI}(\mathrm{KI})$, and $\mathrm{W}-\mathrm{CI}(\mathrm{VI})$, and triple-mutant $\mathrm{W}-\mathrm{CI}(\mathrm{VKI})$. The nucleotide variations in the mutated constructs were confirmed by sequencing (ABI377; Perkin-Elmer Applied Biosystems, Foster City, CA, U.S.A.).

\section{Confirmation of recombinants and mutants in infected plants.}

The identities of the recombinant and mutant viruses inoculated on Cucumis metuliferus was confirmed by restriction analyses and sequencing of the RT-PCR products. For RT$\mathrm{PCR}$, the total RNAs were isolated from the upper leaves of systemically infected plants $14 \mathrm{dpi}$. For ascertaining the recombinants, the PRSV genomic regions at nt 3,153 to 5,014 (primers, MWM2S5014 and PYK3153) and nt 6,956 to 8,891 (primers, MWM4S8991 and PWM6956) were amplified by RT-PCR, and the EcoRV (4,346), SphI (4,694), NheI (7,147), and PstI $(8,176)$ restriction sites (the positions of the sites as nucleotide numbers in parenthesis) unique to $\mathrm{P}-\mathrm{YK}$ cDNA (Fig. 2A) were analyzed. For further confirmation, these RTPCR products were sequenced (ABI377; Perkin-Elmer Applied Biosystems).

For ascertaining the identities of the mutant viruses, the NIa regions of the P-YK mutants (nt 6,363 to 7,643) were amplified by RT-PCR with the primers MPYKX7643 and PYKE6363. Similarly, the corresponding regions of the W-CI mutants were amplified with the primers MWCIX7645 and PWCIE6365. The RT-PCR products were checked for the restriction sites introduced or abolished during the creation of the mutants, and the point mutations were further confirmed by sequencing.

\section{Host reactions.}

The generated recombinant viruses or point-mutated viruses were mechanically introduced and maintained in Cucumis metuliferus plants as described for the in vitro and in vivo infectious clones. Virus inocula were prepared from infected $\mathrm{Cucu}$ mis metuliferus plants 10 dpi by grinding $1 \mathrm{~g}$ of leaf in $20 \mathrm{ml}$ of inoculation buffer (0.01 M phosphate buffer, $\mathrm{pH}$ 7.0). Each virus inoculum was introduced into eight papaya plants at seven- to eight-leaf stage and five Cucumis metuliferus plants at two-true-leaf stage. The experiments were repeated four times and all inoculated plants were maintained in a temperature-controlled greenhouse $\left(23\right.$ to $28^{\circ} \mathrm{C}$, without supplementary light) for observation of symptom development.

\section{Detection of virus accumulation by ELISA and Western blotting analysis.}

To confirm the papaya infectivity of all the recombinant viruses maintained in Cucumis metuliferus, plants, were mechanically introduced, at 1:20 dilution with $0.01 \mathrm{M}$ phosphate buffer ( $\mathrm{pH} 7.0$ ), into eight papaya plants at the six-leaf stage. The inoculated plants were kept in a greenhouse $\left(23\right.$ to $\left.28^{\circ} \mathrm{C}\right)$ for observation of symptom development. The presence of viruses in the inoculated plants were also analyzed by ELISA $14 \mathrm{dpi}$ (Yeh and Gonsalves 1984b). The extracts $(200 \mu \mathrm{l})$ of plant leaves diluted 100 -fold in coating buffer ( $15 \mathrm{mM} \mathrm{Na}_{2} \mathrm{CO}_{3}, 35$ $\left.\mathrm{mM} \mathrm{NaHCO}, 0.02 \% \mathrm{NaN}_{3}, \mathrm{pH} 9.6\right)$ were loaded in individual wells of ELISA plates (Nunc, Naperville, IL, U.S.A.) at $37^{\circ} \mathrm{C}$ for $1 \mathrm{~h}$. After rinsing three times with PBST (phosphate-buffered saline, $\mathrm{pH} 7.4$, containing $0.05 \%$ Tween 20 ), the antiserum against PRSV P-HA (Yeh et al. 1984) diluted 2,000-fold in enzyme-conjugate buffer (PBST with $2 \%$ polyvinylpyrroli- done and $0.2 \%$ ovalbumin) was added to wells, and the plates were incubated at $37^{\circ} \mathrm{C}$ for $1 \mathrm{~h}$. After washing the wells three times with PBST, $100 \mu$ l of alkaline phosphatase-conjugated goat anti-rabbit immunoglobulin (KPL, Inc., Gaithersburg, MD, U.S.A.) diluted 5,000-fold in enzyme-conjugate buffer was added to each well, and the plates were incubated at $37^{\circ} \mathrm{C}$ for $1 \mathrm{~h}$. After washing the wells three times with PBST, $100 \mu \mathrm{l}$ of a $1 \mathrm{mg} / \mathrm{ml}$ solution of $\rho$-nitrophenyl phosphate (SigmaAldrich Corporation, St. Louis) in substrate buffer $(100 \mathrm{mM}$ diethanolamine buffer, $\mathrm{pH}$ 9.6) was added. The absorbance at $405 \mathrm{~nm}$ was measured on an ELISA reader (Elx800, Bio-Tek Instruments, Inc., Winosski, VT, U.S.A.) 30 min after the addition of enzyme substrate.

The presence of PRSV mutants in papaya and Cucumis metuliferus plants with or without symptoms $14 \mathrm{dpi}$ were also analyzed by Western blotting analysis. Leaf tissues of the plants were ground in 4 volumes (wt/vol) of reducing sample buffer $(62.5 \mathrm{mM}$ Tris-HCI, $\mathrm{pH} 6.8,2 \%$ sodium dodecyl sulfate [SDS], 3\% 2-mercaptoethanol, 10\% glycerol, $0.005 \%$ bromophenol blue). Total proteins of individual samples $(7.5 \mu \mathrm{l})$ were resolved on a $10 \%$ SDS-polyacryamide gel, and the profile was transferred to a nitrocellulose membrane. The polyclonal antiserum against PRSV P-HA (Yeh et al. 1984) in 1:2,000 dilution and alkaline phosphatase conjugated goat anti-rabbit antiserum in 1:5000 dilution were used for detection. NBT ( $\rho$-nitro blue tetrazolium chloride) and BCIP (5bromo-4-chloro-3-indoyl-phosphate $\rho$-toluidine salt) were used for coloration.

\section{NIaPro 3-D structural prediction.}

Based on the crystal structure of NIaPro of TEV (Protein data bank ID code 1LVB) elucidated by Nunn and associates (2005), the 3-D structures of NIaPros of P-YK and W-CI were predicted by using the modeling package MODELLER (Lambert et al. 2002). The predicted 3-D structures of the NIaPros of P-YK and W-CI were compared with that of NIaPro of TEV (Nunn et al. 2005) using the Deep View program (Guex and Peitsch 1997) to analyze the critical aminoacid positions of the P-YK and W-CI.

\section{ACKNOWLEDGMENTS}

This research was partly supported by the NSC grants 93-2752-B-005002-PAE, 94-2752-B-005-002-PAE, and 94-2752-B-005-002-PAE from the National Science Council of the Republic of China on Taiwan.

\section{LITERATURE CITED}

Ayme, V., Petit-Pierre, J., Souche, S., Palloix, A., and Moury, B. 2007. Molecular dissection of the Potato virus $Y$ VPg virulence factor reveals complex adaptations to the pvr2 resistance allelic series in pepper. J. Gen. Virol. 88:1594-1601.

Bateson, M. F., Henderson, J., Chaleeprom, W., Gibbs, A. J., and Dale, J. L. 1994. Papaya ringspot potyvirus: Isolate variability and the origin of PRSV type P (Australia). J. Gen. Virol. 75:3547-3553.

Bateson, M. F., Lines, R. E., Revill, P., Chaleeprom, W., Ha, C. V., Gibbs, A. J., and Dale, J. L. 2002. On the evolution and molecular epidemiology of the potyvirus Papaya ringspot virus. J. Gen. Virol. 83:2575-2585

Beauchemin, C., Boutet, N., and Laliberte, J. F. 2007. Visualization of the interaction between the precursors of $\mathrm{VPg}$, the viral protein linked to the genome of Turnip mosaic virus, and the translation eukaryotic initiation factor iso 4E in Planta. J. Virol. 81:775-782.

Carrington, J. C., and Dougherty, W. G. 1987. Small nuclear inclusion protein encoded by plant potyvirus genome is a protease. J. Virol. 61:25402548.

Chang, C. A. 1979. Isolation and comparison of two isolates of Papaya ringspot virus in Taiwan. J. Agric. Res. China 28:207-216.

Chen, K. C., Wang, C. H., Liu, F. L., Su, W. C., and Yeh, S. D. 2003. The NIa gene of Papaya ringspot virus is the host determinant for papaya infection. Page 362 in: 7th International Congress of Plant Molecular Biology, S25-14. Barcelona, Spain. 
Chiang, C. H., and Yeh, S. D. 1997. Infectivity assays of in vitro and in vivo transcripts of papaya ringspot potyvirus. Bot. Bull. Acad. Sin. 38:153-163.

Chu, M., Lopez-Moya, J., Llave-Correas, C., and Pirone, T. 1997. Two separate regions in the genome of the Tobacco etch virus contain determinants of the wilting response of Tabasco pepper. Mol. Plant-Microbe Interact. 10:472-480.

Davis, M. J., and Ying, Z. 1999. Genetic diversity of the Papaya ringspot virus in Florida. Proc. Fla. State Hortic. Soc 112:194-196.

De La Rosa, M., and Lastra, R. 1983. Purification and partial characterization of Papaya ringspot virus. Phytopathologische Zeitschrift 106:329336

De Mejia, M. V. G., Hiebert, E., and Prucifull, D. E. 1985. Isolation and partial characterization of the amorphous cytoplasmic inclusions associated with infections caused by two potyviruses. Virology 142:24-33.

Dougherty, W. G., and Carrington, J. C. 1988. Expression and function of potyviral gene products. Annu. Rev. Phytopathol. 26:123-143.

Dougherty, W. G., and Dawn Parks, T. 1991. Post-translational processing of the Tobacco etch virus 49-kDa small nuclear inclusion polyprotein: Identification of an internal cleavage site and delimitation of VPg and proteinase domains. Virology 183:449-456.

Francki, R. I. B., Fauquet, C. M., Knudson, D. L., and Brown, F. 1991. Classification and Nomenclature of Viruses. In: Fifth Report of the International Committee on Taxonomy of Viruses (Arch. Virol. Suppl.). Springer, Wien and New York, New York.

Gonsalves, D. 1998. Control of Papaya ringspot virus in papaya: A case study. Annu. Rev. Phytopathol. 36:415-437.

Gonsalves, D., and Ishii, M. 1980. Purification and serology of Papaya ringspot virus. Phytopathology 70:1028-1032.

Guex, N., and Peitsch, M. C. 1997. SWISS-MODEL and the SwissPdbViewer: An environment for comparative protein modeling. Electrophoresis 18:2714-2723.

Hong, Y., Levay, K., Murphy, J. F., Klein, P. G., Shaw, J. G., and Hunt, A. G. 1995. A potyvirus polymerase interacts with the viral coat protein and VPg in yeast cells. Virology 214:159-166.

Lambert, C., Léonard, N., De Bolle, X., and Depiereux, E. 2002. ESyPred3D: Prediction of proteins 3D structures. Bioinformatics 18:1250-1256.

Léonard, S., Viel, C., Beauchemin, C., Daigneault, N., Fortin, M. G., and Laliberté, J.-F. 2004. Interaction of VPg-Pro of Turnip mosaic virus with the translation initiation factor $4 \mathrm{E}$ and the poly(A)-binding protein in planta. J. Gen. Virol. 85:1055-1063.

Li, X. H., and Carrington, J. C. 1995. Complementation of tobacco etch potyvirus mutants by active RNA polymerase expressed in transgenic cells. Proc. Natl. Acad. Sci. U.S.A. 92:457-461.

Li, X. H., Valdez, P., Olvera, R. E., and Carrington, J. C. 1997. Functions of the Tobacco etch virus RNA polymerase (NIb): Subcellular transport and protein-protein interaction with $\mathrm{VPg} /$ proteinase (NIa). J. Virol. 71:1598-1607.

Lu, R., Martin-Hernandez, A. M., Peart, J. R., Malcuit, I., and Baulcombe, D. C. 2003. Virus-induced gene silencing in plants. Methods 30:296303

Martelli, G. P., and Russo, M. 1976. Unusual cytoplasmic inclutions induced by Watermelon mosaic virus. Virology 72:352-362.

Mestre, P., Brigneti, G., and Baulcombe, D. C. 2000. An Ry-mediated resistance response in potato requires the intact active site of the NIa proteinase from Potato virus $Y$. Plant J. 23:653-661.

Noa-Carrazana, J. C., González-de-León, D., S., R.-C. B., Piñero, D., and L., S.-R. 2006. Distribution of Papaya ringspot virus and Papaya mosaic virus in papaya plants (Carica papaya) in Mexico. Plant Dis. 90:1004-1011.

Noa-Carrazana, J., González-de-León, D., and Silva-Rosales, L. 2007. Molecular characterization of a severe isolate of Papaya ringspot virus in Mexico and its relationship with other isolates. Virus Genes 35:109-117.

Nunn, C. M., Jeeves, M., Cliff, M. J., Urquhart, G. T., George, R. R., Chao, L. H., Tscuchia, Y., and Djordjevic, S. 2005. Crystal structure of Tobacco etch virus protease shows the protein $\mathrm{C}$ terminus bound within the active site. J. Mol. Biol. 350:145-155
Plante, D., Viel, C., Léonard, S., Tampo, H., Laliberté, J.-F. and Fortin., M. G. 2004. Turnip mosaic virus VPg does not disrupt the translation initiation complex but interferes with cap binding. Physiol. Mol. Plant Pathol. 64:219-226.

Provvidenti, R., and Gonsalves, D. 1982. Resistance to Papaya ringspot virus in Cucumis metuliferus and its relationship to resistance to Watermelon mosaic virus 1. J. Hered. 73:239-240.

Purcifull, D. E., and Edwardson, J. R. 1967. Watermelon mosaic virus: Tubular inclusion in pumpkin leaves and aggregates in leaf extracts. Virology 32:393-401.

Purcifull, D. E., and Hiebert, E. 1979. Serological distinction of Watermelon mosaic virus isolates. Phytopathology 69:112-116.

Purcifull, D. E., Edwardson, J. R., Hiebert, E, and Gonsalves, D. 1984. Papaya ringspot virus. Page 292 in: CMI/AAB Descriptions of Plant Viruses. Association of Applied Biologists, Warwick Enterprise Park, Wellesbourne, Warwick, U.K.

Riechmann, J. L., Lain, S., and Garcia, J. A. 1992. Highlights and prospects of potyvirus molecular biology. J. Gen. Virol. 73:1-16.

Robaglia, C., and Caranta, C. 2006. Translation initiation factors: A weak link in plant RNA virus infection. Trends Plant Sci. 11:40-45.

Roudet-Tavert, G., Michon, T., Walter, J., Delaunay, T., Redondo, E., and Le Gall, O. 2007. Central domain of a potyvirus VPg is involved in the interaction with the host translation initiation factor eIF4E and the viral protein HcPro. J. Gen. Virol. 88:1029-1033.

Salvador, B., Delgadillo, M. O., Sáenz, P., Garcia, J. A. and Simón-Mateo, C. 2008. Identification of Plum pox virus pathogenicity determinants in herbaceous and woody hosts. Mol. Plant-Microbe Interact. 21:20-29.

Schaad, M. C., Jensen, P. E. and Carrington, J. C. 1997. Formation of plant RNA virus replication complexes on membranes: Role of an endoplasmic reticulum-targeted viral protein. EMBO (Eur. Mol. Biol. Organ.) J. 16:4049-4059.

Tözsér, J., Tropea, J. E., Cherry, S., Bagossi, P., Copeland, T. D., Wlodawer, A., and Waugh, D. S. 2005. Comparison of the substrate specificity of two potyvirus proteases. FEBS (Fed. Eur. Biochem. Soc.) Lett. 272:514-523.

Urcuqui-Inchima, S., Haenni, A. L., and Bernardi, F. 2001. Potyvirus proteins: A wealth of functions. Virus Res. 74:157-175.

Wang, C. H., and Yeh, S. D. 1997. Divergence and conservation of the genomic RNAs of Taiwan and Hawaii strains of Papaya ringspot potyvirus. Arch. Virol. 142:271-285.

Wang, J., and Yeh, S. 1998. Characterization of the Papaya ringspot vitus W type isolates collected from different areas of Taiwan by host reactions, immunodiffusion test and RT-PCR. Plant Prot. Bull. 40:383-395.

Webb, R. E., and Scott, H. A. 1965. Isolation and identification of Watermelon mosaic virus 1 and 2. Phytopathology 55:895-900.

Wittmann, S., Chatel, H., Fortin, M., and Laliberte, J.-F. 1997. Interaction of the viral protein genome linked of turnip mosaic potyvirus with the translational eukaryotic initiation factor (iso) 4E of Arabidopsis thaliana using the two-hybrid system. Virology 234:84-92.

Yeam, I., Cavatorta, J. R., Ripoll, D. R., Kang, B. C., and Jahn, M. M. 2007. Functional dissection of naturally occurring amino acid substitutions in eIF4E that confers recessive potyvirus resistance in plants. Plant Cell 19:2913-2928.

Yeh, S. D., and Gonsalves, D. 1984a. Evaluation of induced mutants of Papaya ringspot virus for control by cross protection. Phytopathology 74:1086-1091.

Yeh, S. D., and Gonsalves, D. 1984b. Purification and immunological analysis of cylindrical-inclusion protein induced by Papaya ringspot virus and Watermelon mosaic virus 1. Phytopathology 74:1273-1278.

Yeh, S. D., and Gonsalves, D. 1985. Translation of Papaya ringspot virus RNA in vitro: Detection of a possible polyprotein that is processed for capsid protein, cylindrical-inclusion protein, and amorphous-inclusion protein. Virology 143:260-271.

Yeh, S. D., Gonsalves, D., and Provvidenti, R. 1984. Comparative studies on host range and serology of Papaya ringspot virus and Watermelon mosaic virus 1. Phytopathology 74:1081-1085.

Yeh, S. D., Jan, F. J., Chiang, C. H., Doong, T. J., Chen, M. C., Chung, P. H., and Bau, H. J. 1992. Complete nucleotide sequence and genetic organization of Papaya ringspot virus RNA. J. Gen. Virol. 73:2531-2541. 